\title{
Letting the mask slip: the shameless fame of Sierra Leone's Gongoli
}

\author{
Samuel Mark Anderson
}

\section{Introduction: face off}

Swollen nose. Elephantine ears. Bugged-out eyes. Bald head and frayed whiskers. Distended lips drooped around mangled and meagre teeth smeared with the cruddy remnants of kola and roasted palm nuts. The repugnant mug of Gongoli $^{1}$ is one of the most beloved in Mendeland (Figure 1). Unlike other performing spirits - known as haleisia in Mende, debuls or 'devils' in Krio, or 'masquerades' in academic English - Gongoli's pervasive popularity is rooted in neither splendour nor esteem. His oversized, grotesque head is usually too ungainly to stay on the performer's head without being supported by at least one hand. Dressed in rags that barely cover his mortal human flesh, Gongoli brandishes a nondescript stick as crutch, whip and priapic prosthesis. Gongoli is the consummate party-crasher, barging into any village festivity uninvited. $\mathrm{He}$ is usually encountered either stumbling from one household to the next looking for laughs and handouts or busting through a ring of onlookers during live shows, distracting the crowd with flailing antics and mimed sex acts to the flustered dismay of whichever dancer, devil or ritualist thought they had sole authority over the spectator's gaze. In spite of, or because of, his profligate transgressions, Gongoli stands among the most celebrated figures in Mende tradition and his popularity has spread throughout Sierra Leone.

If one were to imagine Gongoli in human form, one might perhaps imagine the inimitable comedian Siloh (Figure 2). Siloh shares Gongoli's bald pate and poor dental hygiene. His bulgy eyes bounce between sleepy indifference, cocksure selfsatisfaction and rude indignation. With enough of an audience, he may clench his face tight and blow his cheeks out so fully that his features morph into a remarkably inhuman spheroid. He is fond of floppy dancing, much of which involves bouncing

\footnotetext{
Samuel Mark Anderson is a lecturer at New York University Abu Dhabi. He is completing a manuscript on the work of spectacle, violence and the mystic arts in post-war Sierra Leone, and researching the role of local, informal and esoteric medical practice in the Ebola crisis and its aftermath. Email: samuel.mark.anderson@gmail.com

${ }^{1}$ Out of deference to his individualistic personality, I treat the word 'Gongoli' as a proper noun when referring to the character, although I italicize it as a foreign word when it serves as an adjective or modifier ('gongoli dancer'). The correct spelling of gongoli is open to some debate. Most Mende speakers and some academic texts insist on konksli or kongoli, arguing that gongoli is a Krio deformation. I use gongoli in this text since I often refer to it as a pan-ethnic figure, the spelling is more familiar in the existing literature, and in spoken pronunciation the ' $k$ 's of $k$ snksli are swallowed so that they are very close to ' $g$ 's. Moreover, many artists in the Kenema region insist that the proper Mende name for gongoli is kskpsi, which is cited by Siegmann and Perani as the name used by the neighbouring Gola and Vai peoples (1976: 46). A further orthographic note: I endeavour to refer to haleisia (singular: halei) when speaking of Mende masked performance, and to debuls or devils when speaking more generally of Sierra Leone.
} 


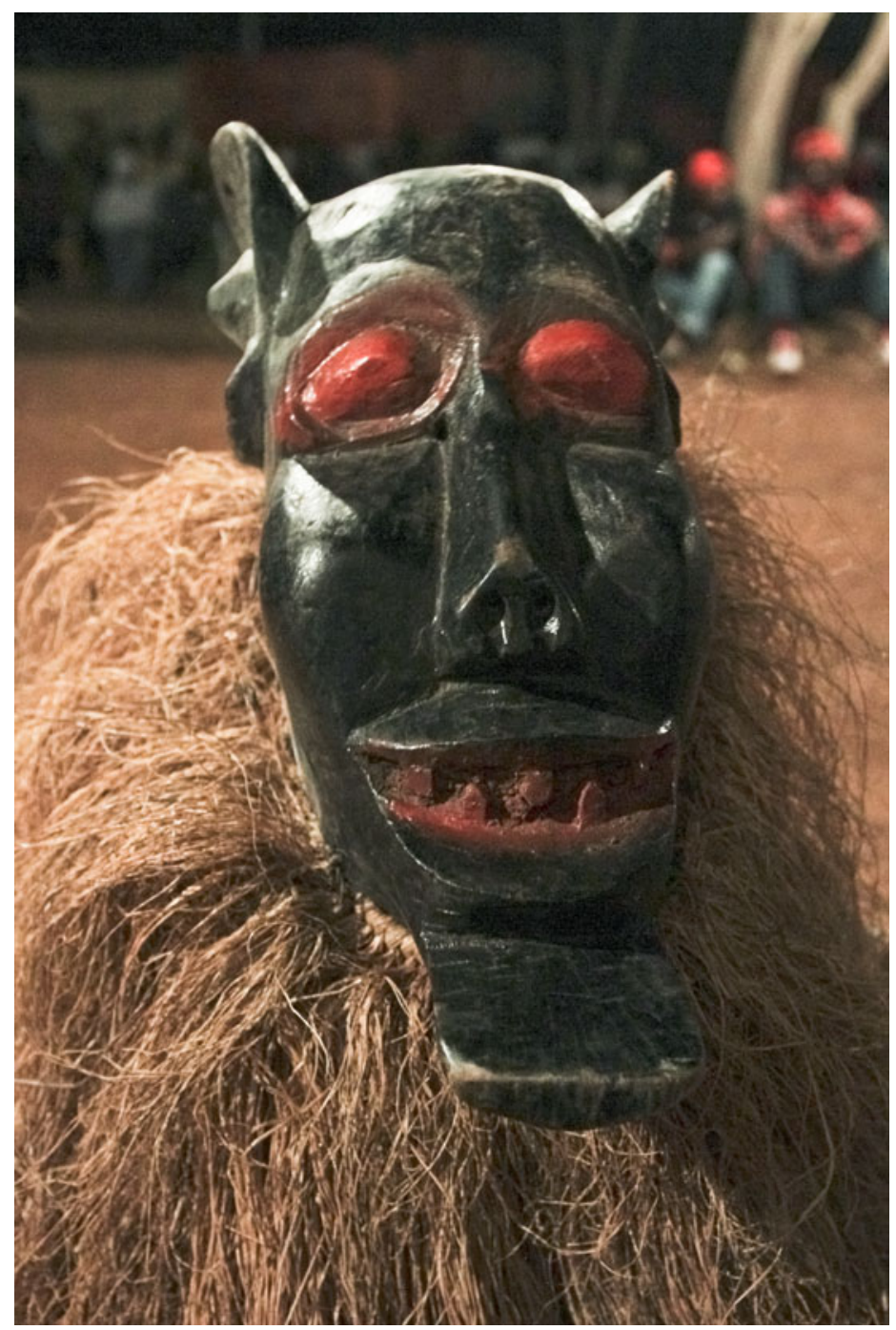

FIGURE 1 Gongoli performed by Jusu 'Mandela' Massaquoi for King Hassan Jalloh and the Warrior Cultural and Mystical Power Dance Troupe, Kailahun, Luawa Chiefdom, 2011.

up and down on the ground, contorting into a ball with one leg behind his neck, and spinning in dirt in a spoof of breakdancing (Figure 3). When I first met Siloh in January 2012, he was frequently seen wearing a T-shirt depicting a picturesque palm tree-lined beach scene below the caption 'Casual Friday'. The garment's layers of accumulated dust and stains suggested that, Friday or not, every day for Siloh is pretty casual. When he strips off whichever shirt he happens to be wearing, a huge bulge of belly is revealed, tucked under the elastic strap of trousers 


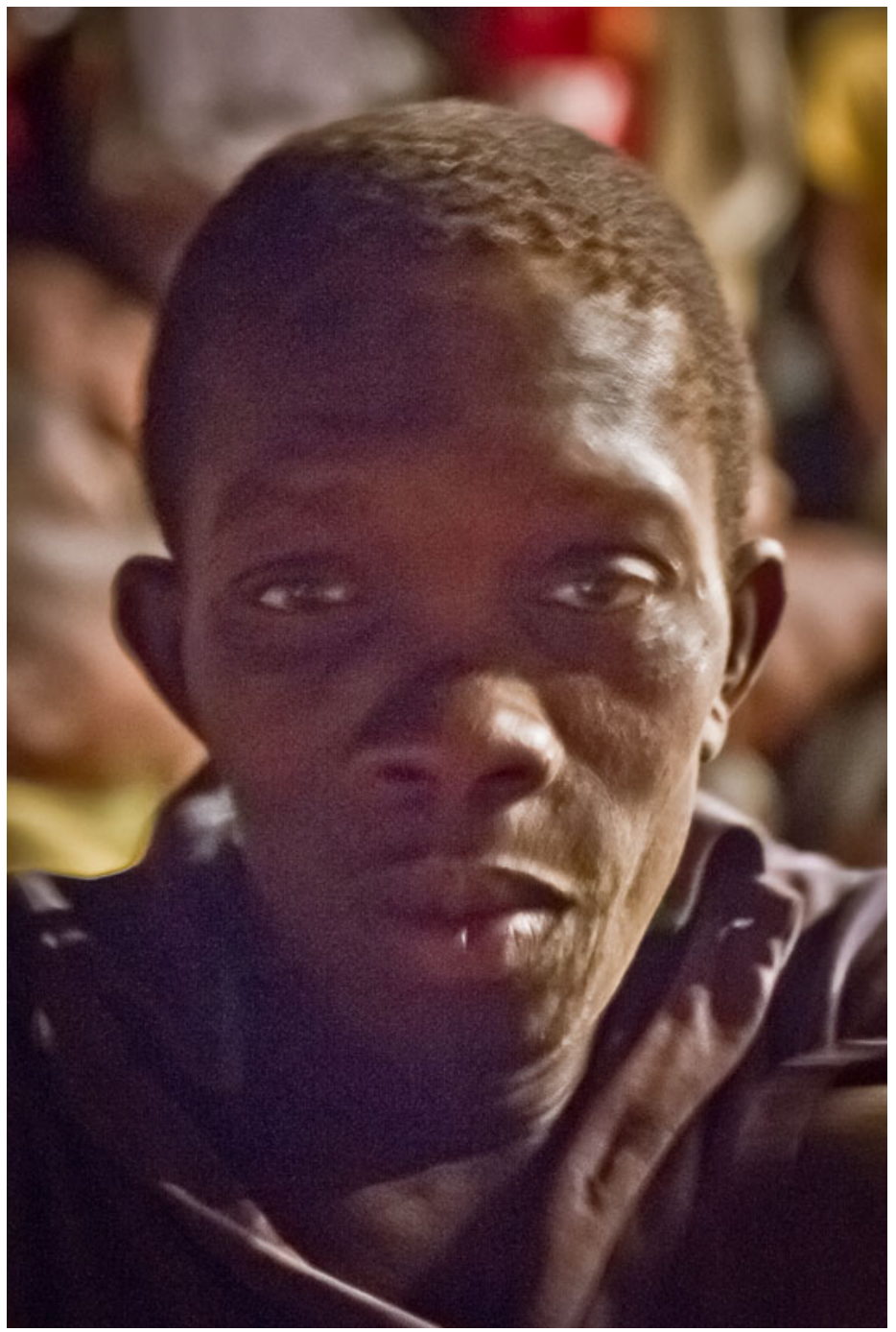

FIGURE 2 Siloh, Gboaama, Njaluahun Chiefdom, 2013.

drawn high over his waist. After sufficient goading, Siloh is often pressured into revealing the source of the bulge, an improbably distended navel that he is capable of sucking into and out of his gut in a literally stomach-turning display of somatic plasticity. A foreigner predisposed to biomedical pathologizing may point to this umbilical herniation as a sign of malnutrition suffered when Siloh was an infant, while his stubby digits and indeterminate age may be indications of congenital anomalies. Yet I never heard anyone describe Siloh as anything other than Siloh. Siloh is one of Mendeland's most surprising celebrities. Mammy Yoko Cultural Dance Troupe, an ad hoc collective of touring entertainers, often finds space for 


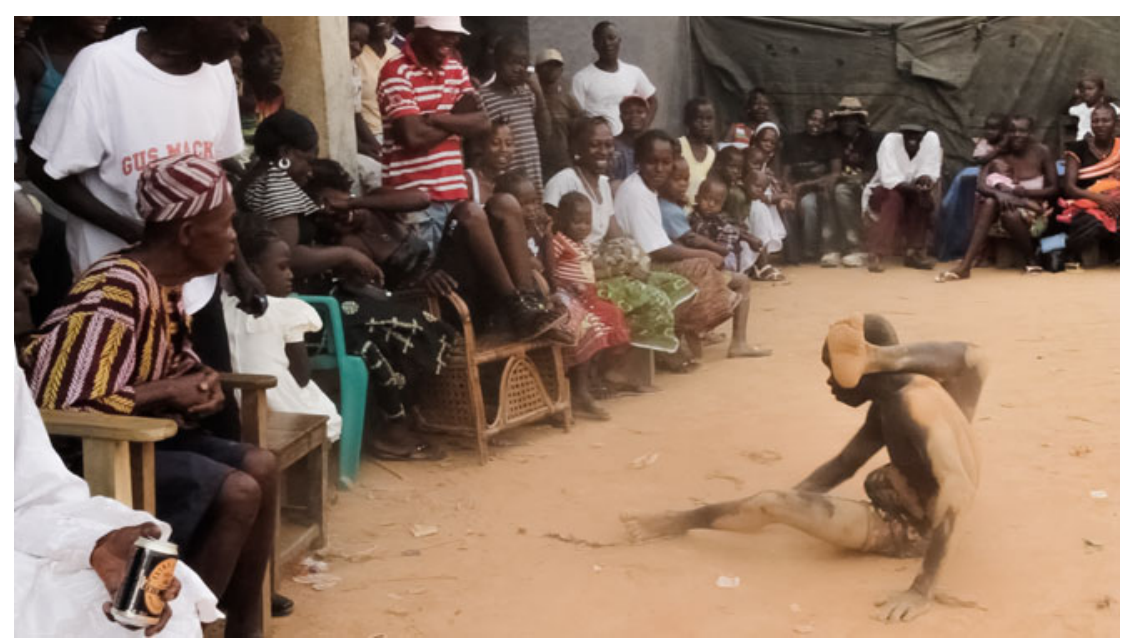

FIGURE 3 Siloh breakdances, Mofindor, Luawa Chiefdom, 2012.

Siloh in their programme of acrobatics, magic acts and other masked debuls. When I travelled with the troupe, children would run after our vehicle chanting his name, a privilege normally reserved for politicians, superstar performing artists, and reluctant foreigners. Like these other visitors, Siloh is exceptional, but unlike those dignitaries whose fame aligns with prevailing status structures, Siloh flips hierarchies as unreservedly as he somersaults across the dance field.

The widespread adoration of Gongoli and Siloh, two paragons of inelegance, challenges the essence of Mende haleisia as noble, potent and dangerous. Indeed, they even make a mockery of haleisia's constitutive mystery, for not only does Siloh act like Gongoli, he often openly acts as Gongoli. Moreover, unlike other haleisia dancers, yet in common with wider practices of gongoli performance, Siloh does little to disguise his individual quirks. Via comical fumbling with his mask, his identity is frequently exposed. Fellow performers even introduce him as 'Siloh Gongoli'. In Cole's memorable formulation (1985), African mask traditions typically dramatize the paradox 'I am not myself', stressing the potential for power and play within claims of self-effacement. Yet Siloh's performance as Gongoli openly enacts his own personality. Through a deceptively simple yet radical subversion of Cole's paradox, Siloh (the performer), Gongoli (the character) and Siloh Gongoli (their coalescence) personify alternate paradoxes: famous masked dancer, adored outsider, sacrilegious spirit and unpredictable tradition.

Mende aesthetics, and those of Sierra Leone more broadly, are steered by widespread concerns regarding yet another powerful paradox: the volatile and suspect correlation between the visible exterior of the surface and the invisible interior of truth. Management of one's appearance is a paramount form of social power, even though everyone is aware that such appearances are liable to be fraudulent. Local conceptions of power and wisdom understand esotericism as fundamental to potency, and the most influential social actors marshal tremendous invisible resources (Ferme 2001; Murphy 1998). Siloh and Gongoli play with and 
against such principles arguing that the ability to camouflage one's personal interests is directly proportional to one's ability to participate and excel in social life.

Tensions between the visible and the invisible reflect those between facades of propriety and hearts of self-interest, between experienced hardship and imagined aspiration. Such tensions are compelling and dangerous, often erupting into anguish and violence. Youth is the period during which one is confronted most directly by the breach between one's limitations and one's aspirations, the restricted person everyone else sees and the potential person one believes oneself to be. Scholars working across Africa understand youth not as a set age range but as a transitional period in which those who fail to fulfil expectations of adulthood become 'stuck' in a perpetual state of 'waithood' (Honwana 2012; Sommers 2012). Sierra Leone's 1991-2002 civil war has been frequently characterized as a 'crisis of youth' (Peters 2011; Peters and Richards 1998), and despite the influx of NGO-sponsored internationalist narratives of youth empowerment in post-war Sierra Leone, such impediments still define many lives (Bolten 2012; Shepler 2014). Yet this breach is symptomatic of a more pandemic existential crisis of interior versus exterior self. One tactic to overcome this crisis is to foment revolution. Another is to 'fake it until you make it' through bluff (Newell 2012). Yet a third option is to contravene and undermine systemic veneration of successful self-obfuscation through radical shamelessness.

Siloh and Gongoli stand among a panoply of Sierra Leonean performers who mobilize shamelessness, disarray, artlessness, exposure and egotism for comic and subversive potential, playing with the pressures that abound where appearance is at once everything and nothing. Such aesthetics celebrate the ability of certain remarkable individuals to carve out exceptions to dominant rules of conformity. Across a variety of conventions - from trickster stories to urban 'shit devils' to radio and video comedians - Sierra Leonean artists amuse their audiences with impudent explorations of the collisions that set the exterior limits and expectations of human society against the interior desires and pretensions of human individuality.

Gongoli's promise of exorbitant individualism is complicated by his widespread replication, pan-ethnic ubiquity, long-standing popularity, and an indifference to his ancestry. While I mainly write about his place in Mende-speaking regions - as those are Siloh's stomping grounds and the areas in which I have come to know Gongoli best - Gongoli and similar masked figures proliferate in many neighbouring communities throughout Sierra Leone and Liberia, suggesting that his antics have national and regional relevance. Wherever I encountered them, most gongoli players, including Siloh, pulled from a familiar repertoire of stock comic bits that largely remain consistent with descriptions of pre-war performers, suggesting long-standing appeal but also a certain conservatism in contemporary practice. ${ }^{2}$

\footnotetext{
${ }^{2}$ Notably topical exceptions that I witnessed included a particularly committed and comically gifted performer in Bombohun, Jawei Chiefdom, who worked the awkward interruption of a mobile phone call into one of Gongoli's standard bits of stalling and distraction, and a mock election in honour of coming presidential campaigns conducted by Jusu 'Mandela' Massaquoi as Gongoli during a performance by the Warrior Cultural and Mystical Power Dance Troupe in Kailahun Town, Luawa Chiefdom.
} 
After watching numerous repetitions of Gongoli's shtick in geographically and temporally diverse contexts, local observers speak of him in the present tense as an ageless, unchanging figure. I follow their lead here, not to indulge in an ethnographic present, but rather to reproduce the almost gnomic aspect applied to the acts of an iconic figure considered timeless. Gongoli's ahistoricism is exacerbated by the general dearth of information about his past. His published origin stories are contradictory, his profane nature has led to neglect by local historians, and even gongoli performers, who generally take up the mask autonomously and opportunistically, have little knowledge or interest in the character's roots. While I gesture towards some possible progenitors in the second section of this article, my overall aim is not to establish Gongoli's genealogy (a task with which a future, more systematic project might find more success). Rather, I outline a more generalizable aesthetic of shameless individuality that many Sierra Leoneans enjoy and exploit in various ways and to various ends. The irony of Gongoli, one common to many popular forms, is that this paragon of individualistic excess has, in his wanton reduplication, become largely conventional. Siloh Gongoli's singular celebrity thus offers a restoration of the gongoli tradition's core promise of exceptional selfhood.

\section{Aesthetics of exception}

\section{Outsider as act}

Gongoli ranks among a diverse array of performance practices perpetuated by Mende artists and social groups. Mende language and identity dominate Sierra Leone's Southern and Eastern Provinces, while partaking in cultural idioms common throughout the wider region, including Guinea and Liberia (d'Azevedo 1962). Among these shared customs is the important role of gendered initiatory sodalities, known in Mende as Poro for men and Sande for women, and often described in academic literature and by their own members as the quintessential 'secret societies'. These societies ideally recruit all eligible members of the village or township, educate them in proper behaviour, and engage in political activities that both complement and check institutions of the chieftaincy and the postcolonial state. While most of their activities are hidden from non-members, these societies materialize publicly through manifestations of haleisia (singular: halei) that embody the principles of their respective societies, emphasizing the political and spiritual force of esoteric knowledge and coloured either by virile ferocity in the case of Poro's gbini, or by graceful discipline in the case of Sande's dancing sowei. In fact, haleisia refers to masked performers, religious materials, local and Western medicines, and the initiatory societies themselves, prompting Jẹdrej to define halei broadly as both 'mystery' and 'ritual separator' (1976: 247-8) and Murphy to define it as any object with hidden, transformative powers (1998: 567). Society haleisia are usually restricted to events by and for the societies themselves, so smaller collectives and individual entrepreneurial artists sponsor subsidiary haleisia that relinquish some mystic authority for freedom to perform more widely. Gongoli epitomizes a kind of parasitic halei that rarely takes centre stage but instead forages around the margins of other festivities. 
Gongoli's peripheral role in Mende culture has led to a dearth of research. While the magnificent performances of soweisia, the most internationally renowned women's mask tradition, are well documented (Boone 1986; MacCormack 1979; Phillips 1995), and Poro and its activities are among the most productive sites of regional anthropological research (Bellman 1984; Little 1965; Murphy 1998), gongoli performance is usually summarized in only a few short sentences. Western taxonomists sometimes describe Gongoli as a Poro halei, but Gongoli has no relationship with Poro beyond the fact that its bearers, like all Mende men, are ideally Poro members. Siegmann and Perani characterize Gongoli as 'a vehicle for the ritualized reduction of social tensions through social commentary and criticism' (1976: 46), yet it would be a stretch to call Gongoli a 'ritual clown' since no rituals revolve around his activities; his improvisations rather interrupt ritual, whether initiation, funeral, or political rally. Furthermore, his credentials as a political satirist (Jędrej 1991: 10-11) risk overstatement, as the pleasure of every Gongoli I witnessed lay in their gross simplicity. The lack of substantial academic commentary is mirrored by local Mende observers, as his comedic character leads most to dismiss Gongoli as a subject of serious inquiry.

Nonetheless, Gongoli is almost universally recognized and universally adored in Sierra Leone. During 2011-13, when I travelled across Sierra Leone in the company of touring cultural groups to research the role of spectacle in post-war society, I often encountered gongoli performers emerging from and disappearing back into the crowds at a variety of events. ${ }^{3}$ The performers were usually marginal to some degree: village men outside hierarchies of Poro or chiefly families, independent youth who sometimes gathered in small bands around Gongoli, or touring performers such as Siloh who lived precariously off tips they might find at festive events.

Gongoli performers use both a set of familiar stock antics and their own improvised comic gags to mock a host of sacrosanct Mende values. The character's creaky frailty upends reverence for elders. His poor management of libido and bodily functions, whether expressed through copulatory pelvic spasms or mismanagement of nasal mucus, are an affront to propriety. One of his most popular gimmicks begins when he enjoins two audience members to hold his stick lengthwise like a high jump. He backs up, stretches comically, races towards the hurdle as if to vault over, but then skids to a stop and commands it higher. $\mathrm{He}$ continues to repeat this cycle until the volunteers are stretched uncomfortably and standing on tiptoe. In one final dramatic charge, he bears down with full

\footnotetext{
${ }^{3}$ Over the two performance seasons (2011-13) during which I travelled with a number of touring cultural troupes, I attended nineteen Mammy Yoko programmes in fourteen towns and villages across Southern and Eastern Sierra Leone; Siloh was with them for about half of those events and performed as Gongoli about half the time he was present. Another dancer sometimes played Gongoli for Mammy Yoko in Siloh's absence, often using the same kinds of gags, although, while his Gongoli was praised by the crowd, the performer himself was not recognized by name. Most of the other established cultural troupes with whom I travelled had a gongoli performer (or at least a gongoli mask that a dancer could throw on), and an innumerable number of other gongoli performers appeared in the course of my research during village festivals, processions, political rallies and other festivities. In 2015, I had the opportunity to interview five gongoli artists from villages near Kenema, Daru and Kailahun.
} 
velocity, yet speeds under the bar and straight out of the playing field. Such boastful yet disastrous attempts at athletic feats satirize the bravado fundamental to Mende conceptions of masculinity.

Most thoroughly, Gongoli subverts the vaunted status of Mende haleisia. Unlike most other devils, he is never accompanied by an aggrandizing entourage of assistants. More likely, he is surrounded by an unruly mob of uninitiated children. Rather than carefully proscribed choreography typical of higher haleisia, his gait vacillates anywhere between a creaky totter of aged infirmity and a heedless, headlong dash of frantic cowardice. When he does dance, his futile attempts at mimicked virtuosity tumble into parodic exaggeration of other devils, contemporary disco steps, or vulgar gestures of fornication. While many other haleisia speak or sing, Gongoli uses a voice so laden with a thick, nasal twang and so muffled by his enormous wooden visage that he often has trouble getting his point across. Most of what he says is bumptious balderdash anyway. He only claims one song, the ludicrous chant Gongoli nyandengs! A fayn! ('Gongoli is beautiful [Mende]! I'm beautiful [Krio]!'), which is sometimes twisted to the more combative Gongoli nyamungs! A fayn pas yu! ('Gongoli is ugly [Mende]! I'm better looking than you [Krio]!').

These lampoons of form are eclipsed by Gongoli's mockery of the very essence of masking practice: anonymity of the performer. His slipshod appearance is an inversion of the carefully crafted construction of most debuls, and his meagre coverings barely disguise the identity of the dancer within. One skit mocks both masking and Islam, two of the most prevalent forms of sacred power. Attempting Islamic observance, Gongoli falls to the ground and prostrates himself in a flustered simulation of the solemn and precise ritual of Salat prayer, muttering a stream of rough Arabic (see also Hommel 1981: 61). When he drops his forehead to the earth in supplication, he discovers to his chagrin that his bulbous cranium is too massive to lift from its dusty bed. With increasingly frantic scrambling and dizzy gyrations around the immobile pivot of his corpulent forehead, Gongoli struggles to stand. In a final fit of frustration, Siloh's head pops out of the mask, face fully uncovered, and he is finally able to get leverage to hoist the mask off the ground and over his head. Siloh Gongoli stands frozen for a moment, as if to check if anyone has noticed his indiscretion, then, in spite of the audience's boisterous snickering, he jumps back into his antics as if nothing has happened. ${ }^{4}$

Mammy Yoko, the touring cultural troupe Siloh follows most regularly, often exploits such irreverence to cap their evening programme of acrobatics, dance and mystical displays. The programme typically climaxes with the show-stopping wizardry of the troupe's resident bowui devil, a 'haystack'-style halei that spins in hypnotizing tempests and extends to inhuman dimensions (Siegmann and Perani 1976: 46). As the bowui swirls off stage, Siloh Gongoli scampers forward. Attempting to mimic the mystically awesome ability of the bowui to grow to extraordinary heights, Gongoli goads the troupe's drum team into underscoring his own demonstration. Punctuated by each staccato rap of the side drum, Gongoli

\footnotetext{
${ }^{4}$ I witnessed Siloh reiterate this sequence multiple times while roving from house to house to collect tips in the afternoons before shows at two villages where the Mammy Yoko troupe performed. I also saw a number of other gongoli performers play similar skits in other contexts.
} 
ratchets his head higher and higher. Unfortunately for Gongoli, his raffia crown is much shabbier than the bowui's lush, billowing cloak, and within a few cranks, Siloh's wide-eyed visage is fully revealed to the cheering crowd. Suddenly aware of his exposure, Siloh drops the mask and flees the scene, dissolving the crowd and the night's festivities with a wave of uproarious mirth.

\section{Outsider as archetype}

Through acts of exposure, Gongoli undertakes a meta-commentary on masking that acknowledges the artifice of the mask and violates its sacrosanct principles of anonymity and self-effacement. Somehow, Gongoli is allowed to literally 'lose face' before his audiences. Siloh and other dancers can only perform these acrobatic reversals of hallowed Mende values thanks to the nature of Gongoli's classification among haleisia.

Mende spectators and other debul aficionados, including art historians and anthropologists, distinguish separate categories of haleisia, roughly differentiating those reserved for 'society business' from those who are available for general gladines (Krio for 'amusement') in what Durkheimian scholars might classify as an opposition of the sacred to the profane (Durkheim 1915; Reinhardt 1979; Siegmann and Perani 1976). Less reductively, Phillips notes that 'parallelisms, oppositions, and contrasts' between types highlight the specific qualities of individual halei (1995: 72). Yet while each halei is carefully positioned in relation to those with whom it might perform, such distinctions do not necessarily reflect a greater or lesser protection of anonymity, which is usually carefully guarded in both initiatory society contexts and entertainment-driven ones. While the forms and activities of particular haleisia offer some indications, the logic of their regulation becomes more transparent through patronage.

A scalar view of haleisia patronage reveals a continuum of communities whose declining size and influence correspond almost precisely with diminishing restrictions on performance and the accessibility of a masked dancer's identity. At the weightiest end of the continuum is the patronage of the Poro and Sande initiatory societies. These associations have the most rigid restrictions on their haleisia, since, ostensibly, their performers may play only for society events. Although society membership is limited to one gender or the other, both societies represent the wider town or village, whether through spiritual negotiations with ancestors and the bush or through broad oversight of local political action. Thus, the societies' activities, and consequently those of their haleisia, influence the entire community and, in a significant cosmological sense, all of humanity.

Lower down the scale, other kinds of patronage define more limited associations. The identities of most performers and craftsmen are often subsumed beneath those of their patrons, much as d'Azevedo noted for neighbouring Gola communities in the 1950s (1973: 332). Today, such deferral of prestige prevails whether the patrons are villages, organizations or individuals. On the local government level, chiefs may assemble and promote the work of artists as servants of the chieftaincy for any number of civic functions. A wide array of smaller collectives sponsor haleisia, including agricultural work groups, mutual aid societies and organizations of village youths, often creating or commissioning a devil to raise funds and promote their activities. In touring cultural troupes led by singers or mystic artists, haleisia are subsumed under the name of the star 
performer. In the rare case in which a masked dancer is the troupe leader, his identity becomes widely acknowledged. Such was the case with Kpetema Seiya, the most celebrated mystic performer and falui devil of the pre-war era in Eastern Sierra Leone. Healers and herbalists, frequently lone itinerant specialists without any unified social group, may dance as devils to advertise their own mystic skill set.

At the very bottom of this scale dawdle various disenfranchised performers such as Siloh and most other gongoli dancers. In the midst of a veritable efflorescence of Mende traditional culture in the sixteen years since Sierra Leone's civil war, Gongoli still stands alone. Practically every other traditional performer is the visible arm of a proud collective whose members enthusiastically proclaim their ability to resurrect pre-war culture and restore some degree of normalcy and stability, however illusory that may be. Women's Sande societies and their famed soweisia continue to exemplify such displays. Audiences recognize most devils as representatives of such prominent associations. Not so with Gongoli. Most times I met a gongoli performer at a festival or campaign rally, not only was he uninvited, few bystanders had any idea where he had come from. By the event's end, Gongoli had disappeared, and hardly anyone cared where, in spite of the delight he brought with him.

Across the continuum of haleisia patronage, risks and consequent restrictions of performance are proportional to the scale of the community represented. Broader concerns equal greater risks, greater responsibility, and thus greater protective restrictions. At one extreme lies Poro and the exorbitant penalties imposed on the dancer of the gbini, its most significant devil. If he should fall while carrying his mask, much less allow his identity to be revealed, he will be fined an impossibly costly array of damages including barrels of palm oil, livestock and cash. ${ }^{5}$ While I never witnessed a gbini fall, I was told time and again about the potential fine. Another narrative warns that if a gbini dancer looks inside his headdress while putting it on, it becomes affixed to his head until the performance of a proper sacrifice. Such common and open knowledge suggests that the nature of gbini as mortal human dancer rather than superhuman spirit is not, in and of itself, a secret. However, any such matters may be discussed only in reference to the awesome coercive power of Poro law. The stakes of masked performance diminish from this extreme, as failure to defend the integrity of the devil affects smaller communal interests: from chiefdom, to village, to club or association, to professional troupe, and finally to personal profit. At the end of this spectrum, a performer might be quite blasé about maintaining his anonymity, tossing off his headdress as he leaves the stage or wearing parts of his costume after a performance.

The greater the public whose interests the devil promotes, the more its hidden aspects are vigorously guarded. In abstract terms, this orientation appears to be the inverse of those conceptions espoused by global neoliberalism. As promulgated by numerous NGOs in post-war Sierra Leone, neoliberal ideals emphasize a discourse of individualized human rights that prioritize greater protection of personal privacy while insisting on greater transparency for progressively larger

\footnotetext{
${ }^{5}$ According to songs recorded over a century ago, the fine for falling was a similarly exorbitant four bales of cloth (Migeod 1916: 108).
} 
publics. Under such terms, which have increasing influence in Sierra Leonean political discourse, the opacity of large and influential publics such as Poro and Sande might seem a retrograde model designed to repress personal interests for a collective good. These world views have recently come into direct conflict, particularly during electoral campaigns when Poro and Sande societies have been accused of secretive political collusion and voter harassment. However, masked performers' anonymity cannot be understood simply as promoting abdication of individual agency.

For most Sierra Leoneans, continuous acts of initiation and integration into progressively larger social networks are precisely the pathways towards recognition of one's own agency. Individual agency is always understood in relation to the collective, not in opposition to it. As one ascends through the ranks of community networks, one accumulates the material and social resources necessary to act out one's own programme. Once one attains the status of patron, one is understood as exceptional and capable of mobilizing radical action. This ideal is embodied by gbini performance, which enacts the incontrovertible power of Poro, displays the influence of its members, and provides the primary model of aspiration for most other haleisia.

Exceptionality is embodied at another extreme in Gongoli. Rather than manifesting the 'big man' patron, the ultimate insider through whom a community is imagined (see also Barber 1981), Gongoli is the outsider through whom the community is imagined in reverse. Both gbini and Gongoli are exempted from the rules and regulations of societal norms. Both have the liberty to display inordinate personal difference and to propose radical social transformations. The difference is that the actions of gbini/patron, in representing a wide public, carry incredible personal and social risk. The actions of Gongoli/outsider, lacking the burden of communal ties, carry risk to no one but himself.

Mende performers and commentators agree that only one quality is necessary to play Gongoli: ngufe baa ('shamelessness'). Shame (ngufe) is the lynchpin around which Mende social participation is regulated. Its invocation in a variety of both formally ritualized and casually profane sundisia ('swears') testifies to its central importance: for example, 'If I lie, may the Almighty shame me in this world and the next.' Yet gongoli performers must be ready to debase themselves to any level for a laugh. The most frequently cited example of the extreme degree of required shamelessness is torn trousers, which, in the course of Gongoli's flagellations, reveal the player's private parts, mirroring suggestions that a halei exposing its face is tantamount to a person exposing sexual organs. Few are capable of such self-degradation, including many owners of gongoli masks; I was told that anyone shameless enough might simply borrow a mask for a day from a more reserved proprietor and split whatever tips they receive (Figure 4). Most performers cited poverty or desire for quick cash as the key reasons they began playing Gongoli. Yet despite these base rationales, such humiliation demands a degree of boldness (dri yai or 'dry eye' in Krio) that most Sierra Leoneans lack, leading to a kind of qualified admiration. Certain Gongoli can perform with such bravado that they become locally renowned, attract apprentices, or establish their own hereditary legacies of performance. Such virtuosity is predicated on neither corporeal fitness nor physical danger, but rather on their mastery of social transgression, an acrobatics of shamelessness. 


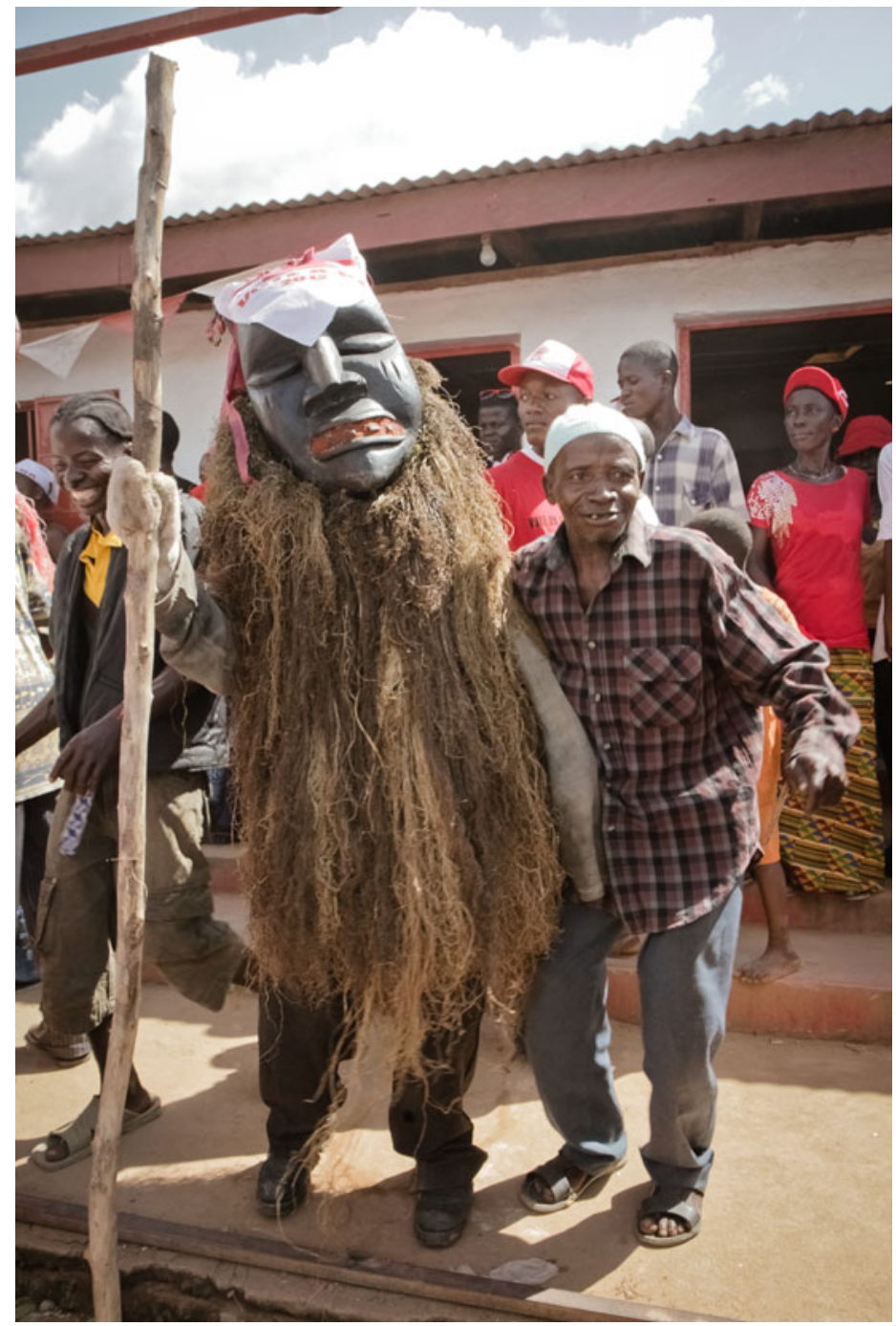

FIGURE 4 Gongoli performed by Sao Musa, with Jina Hindowa, the mask's owner, at an APC political rally, Kailahun, Luawa Chiefdom, 2012.

\section{Trickster, transgressor, travesty, terror}

Even if Siloh and Gongoli are loners, they are not entirely alone. Both participate in a constellation of performers and practices throughout Mendeland and Sierra Leone that mine the gap between collective ideals and individual inadequacies for its comic potential. The following examples offer revealing parallels with Gongoli: the selfish tricks of $\mathrm{Ka}$ Silo, the antisocial deformations of njokui spirits, the parodic flaws of gonde, the transgressive filth of kaka debuls, the anti-gerontocratic 
critique of 'grey-face' comedians, and the nihilist chaos of Musa Wo. In touring this panoply, a number of tantalizing if contradictory origin stories for Gongoli emerge - even though, like itinerant gongoli performers themselves, it remains difficult, and perhaps beside the point, to figure out exactly where Gongoli came from.

\section{Ka Silo}

Siloh and Gongoli's pleasing congruity is cubed by a third figure, one just as infamous and conjured every time Siloh's name is heard: $\mathrm{Ka}$ Silo, anti-hero of many Mende fables. $K a$ is a largely antiquated men's title, silo means 'spider', and the two are often elided as Kaso. While I could never confirm the relation, most who knew him assumed that Siloh had been named after the spider. ${ }^{6}$ The relationship spurred by a shared name, known in Mende as toma, serves as a constant resource for both personal identification and humour. As Ferme notes, toma suggests an absent yet mirroring figure, and toma relations are commonly deployed as a joke of role reversal (2001: 204-12). Absurdity arises from differences between two people sharing the same name and the unnerving suggestion that they might share some secret attribute or, worse, become confused with each other (Jackson 2005: 75-92). While Siloh possesses none of Ka Silo's mercenary egotism, they do share such classically comic features as a bald head and missing teeth. More importantly, they share the qualities of trickster and outsider, simultaneously scorned and loved.

The unsavoury superstar of Mende storytelling, Ka Silo is a spider possessed of all too human failings: greed, gluttony, selfishness and indiscipline. Ka Silo belongs to an extended family of trickster spiders in African folklore, most famously Ananse from Akan stories. Yet Ka Silo is much more bluntly and impotently buffoonish, and unlike Ananse, whose tricks, however self-serving, often have dramatic and transformative world-making effects, Ka Silo's ruses and their aftermath affect no one but himself and his kin. Often, his stories explain various deformities of spiderkind. In a frequently cited narrative, Ka Silo is invited to feasts by his four sons. Rather than committing to any one celebration, Ka Silo believes he can have it all. He ties four ropes around his waist and hands one to each of his sons, telling them to pull the rope when the food is ready. Unfortunately, the rice finishes cooking simultaneously, and Ka Silo is tugged in four directions at once, his belly painfully squeezed tight to its present cramped form. In another story, Ka Silo is warned not to eat beans before other guests arrive. Caught red-handed, he tries to hide his meal under his hat, burning off his hair. Such punishments are not only physical, but also social. Once Ka Silo violates an injunction and suffers deformation, he becomes a pariah (Cosentino 1979: 391).

Just as all persons risk becoming disabled, all persons risk becoming fools (Klapp 1949: 160). Ka Silo spins these two truisms together to reinforce each other in a web of reproach; if one acts selfishly, one jeopardizes one's appearance, both physically and socially. Despite the ominous logic of these lessons, we can laugh at $\mathrm{Ka}$ Silo because he is not entirely human and, like Gongoli, his antics

\footnotetext{
${ }^{6}$ The Mende $o$ is commonly anglicized as 'oh' to differentiate it from the open $\supset$.
} 
challenge no one's reputation but his own. The marginalization of anti-sociality and of disability are elided in such narratives, diagnosed as an overdose of individualism, both in desire and in action.

\section{Medicine societies}

Ugly masks and the threat of disability are not just a laughing matter; a variety of initiatory societies throughout Mendeland have historically used repugnant aesthetics in medical practice. Societies including Njayei, Menda and Humoi regulated a variety of physical and mental illnesses by, in part, regulating proscriptions against the social misbehaviour that would lead to such ailments: for example, incest and other sexual transgressions. I was told that these societies still exist, although it appears that their public and performative dimensions might be lost to the pre-war era. Such events were apparently designed to terrify those who would dare violate the law with the spectacle of deformities they risked incurring (Hommel 1981: 85). Gongoli's ties to these perhaps moribund societies are ambiguous but nonetheless notable. The ugly features of Gongoli have similarly been described as a demonstrative admonition of proper social conduct (for example, Hommel 1981: 61). Moreover, the Njayei society's njokui spirit and Gongoli share physical features, and both may originate with Sherbo peoples, at least according to the speculations of certain informants (Reinhardt 1976: 52-4, 69). Gongoli may therefore have emerged from the comic mitigation of more severe warnings. Whether expressed through the dire threats of pre-war medicine societies or the playful incompetence of Gongoli, the social risks of disability are of special significance to Siloh, a putatively disabled performer.

The role of stigma in humour and social control is disquietingly familiar. Bergson (1914) famously describes laughter as essentially moral, a social means to identify eccentricity often triggered by observing a human body's reduction to mere material thing. Disability and liminality are united in the logic of stigma, when one's social difference undermines the possibility of one's social being (Goffman 1963; Reid-Cunningham 2009: 106). As those perceived to be disabled and those close to them attempt to make sense of disability, we frequently take recourse in moral causation to explicate the universal risks of affliction (Livingston 2005).

Siloh himself, however, maintains an ambiguous relationship to a moral logic of disability. I did once hear a bystander tie Siloh's appearance to moral transgressions of his kin, so such tales likely circulated. When pressed, Mende speakers who knew him called him mamungs, 'half-crazy' or 'half-witted', inborn and incurable, but nonetheless generally functional and harmless. Emcees of the Mammy Yoko troupe and villagers would sometimes goad Siloh into dance competitions with town drunks, or joke with him about his 'girlfriends'. Such jests occasionally crossed a line and drove Siloh to isolate himself from his crowds, but more often he seemed to enjoy the attention and play up to the role. In performance, he found a sphere in which to be an individual, and yet not completely an outsider. ${ }^{7}$ I suspect that he benefits from the ambiguity

\footnotetext{
${ }^{7}$ Other performers marked as 'different' are similarly celebrated onstage in rural Sierra Leone, including a number of very skilled dancers with dwarfism.
} 
between being known as a fool and being known as playing a fool (see also Willeford 1969: 10). Siloh's not entirely real performance as a fool allows audiences flexibility to embrace him fully without fully embracing his foibles. The adoration shown to Siloh and Gongoli, rather than the fear and repulsion imputed to medicine society halesia, suggests that their foolishness is not entirely antisocial; it is also human.

\section{Gonde}

In Mende ritual, the figure of the unsightly can serve as a kind of terrifying vaccination against social ills, but more often it disrupts formal ritual activity with humanizing folly. All the grace, beauty and feminine power wielded by the women's Sande society are embodied by the soweisia (plural), referring to both society elders and masked performers (the latter are also known as ndoli jowei, 'dancing sowei'). Yet Sande acknowledges many sides of women by also welcoming sowei's antithesis: gonde (Figure 5). Gonde revels in reversing the aesthetics of beauty and discretion embodied by soweisia: motley instead of black, sloppy instead of serious, bold instead of discreet. Phillips even describes gonde shamelessly exposing her face in public (1995: 90), and though I never witnessed any gonde performers so brazen, they are definitely more cheeky than their reserved sisters, for instance when they caper to kitschy contemporary disco music.

Gonde parodies sowcisia by quoting their performance yet inverting their values. Parody's ambiguity renders its potential double-edged, as parody can transform its object into either a 'target' or a 'weapon' (J. A. Yunck, quoted in Hutcheon 2000: 52). One could read the impropriety of gonde as either denigration of the nobler soweisia or an admonishment against improper women. In any case, many commentators have noted that parody paradoxically preserves that which it distorts, since audiences may come to know the original through the parody (Dentith 2000: 189; Hutcheon 2000: 108; Rose 1993: 39). In addition to playfully challenging conventions, gonde also serves as a more approachable sowei with whom, unlike her more reserved sisters, one can speak freely, joke, and thus come to know the values of Sande through intimacy as well as awe. ${ }^{8}$

Gonde and Gongoli clearly play with the same toolbox of mocking ineptitude, and, in fact, Gongoli may have originated through an appropriation of gonde tradition, at least as far as Freetown oral histories suggest (Richards 1977: 69). On the performance field, they often find themselves adversaries. One story tells of a race

\footnotetext{
${ }^{8}$ Sande has been known to host another 'masquerade' that takes a more direct form of satire, the samawa. I never saw a samawa performance, but Phillips describes dancers taking on a variety of joking characterizations of men: victims of afflictions such as leprosy or elephantiasis, sanctimonious Muslims, or self-important society leaders. Here, the parodied object is clearly a 'target', i.e. the satirized men who are chided for risking the ritual prohibitions against broaching the privacy of the women's society (Phillips 1995: 90-2). Many other African mask traditions similarly use the licence provided by ritual and disguise as an opportunity for satirical critiques of power (Cole 1985: 13). Gongoli, too, has been described as an agent of the people, resisting and satirizing the elite (Jędrej 1991), yet this characterization is perhaps too optimistically populist. Gongoli has no set political agenda; his radical and risky individualism would not allow it. Besides gonde and samawa, many other figures in both Poro and Sande are exempted from social norms in various ways, such as mabslesia, women who serve in the otherwise all-male Poro (Ferme 2001: 74-9).
} 


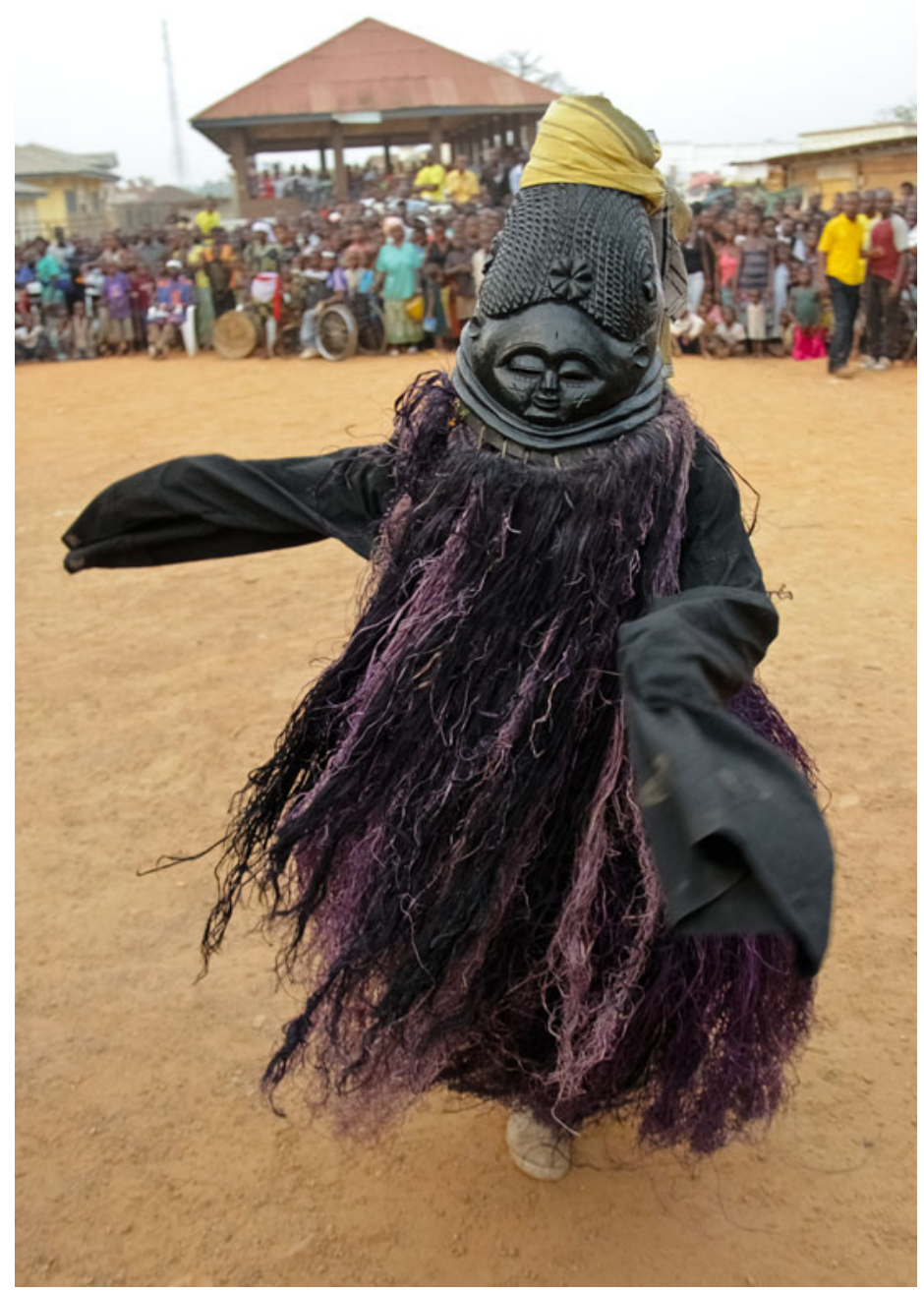

FIGURE 5 The Bandajuma community gonde at an RUFP political rally, Kailahun, Luawa Chiefdom, 2012.

between Gongoli and gonde around the village, which Gongoli wins by running around just one house and declaring 'What is a village but a home' (Hommel 1981: 83). The two characters seem so similar that such rivalries come as no shock. Gonde is, however, a more direct parody than Gongoli. She is restricted to performances sanctioned by Sande and is only fully legible in the presence of soweisia. Gongoli, however, is constrained by neither institution nor reference point, though this freedom comes at the price of social isolation that gonde, as a Sande member, evades. Rather than parodying any specific halei form, 
Gongoli's mockery is more general, a travesty of the very concept of masking itself.

\section{Kaka debul}

Perhaps the epitome of a Sierra Leonean aesthetic of travesty is seen in the kaka debuls (Krio for 'shit devils'), maskers who seemingly embody youth nihilism. Emerging out of the cultural hodgepodge of Freetown slums and provincial towns, the kaka debul consists of a poorly constructed motley of whatever cover can be begged, borrowed or stolen: bed sheets, sweatpants, rope, fishing nets, discarded costumes of other maskers. They scatter throughout the crowds during public holidays and political rallies, singing and dancing with no apparent choreography, unconcerned with disguising their human voice or form. The kaka debul is often described as a child's devil, but those improvisations of boys too young to be initiated, who nonetheless create masked outfits from whatever materials are available to them, demonstrate art and aspiration; indeed, they often serve as informal auditions to gauge future initiates' performance skills. Kaka debuls, on the other hand, deny all aspirations to formality. When youths old enough to be initiated instead play kaka debuls, they assume a more menacing and antisocial energy, an air of arrested development. Kaka debuls eschew the pomp and ceremony of other urban devils, and revel instead in the rejection of all aesthetic and moral propriety. Such apparent inversions lead Cannizzo to characterize the kaka debul as an 'anti-devil' (1983: 127). Yet a more precise characterization might be a travesty of devil procession.

Like 'masquerade', the term 'travesty' originated in costume parties that exploded in popularity throughout eighteenth-century Europe and draws attention to fabricated attire and the fallibility of consonance between interior and exterior (Castle 1986). As a literary and theatrical genre, travesty became a denigrating parody, one that drags high pageantry through low filth (Rose 1993: 5564). Bakhtin collapses travesty with parody when he extols the capacity of 'parodic-travestying' to humiliate and thus humanize classical conventions with 'corrective doubles' (1981: 55-6). In Bakhtin's idealized vision of the carnivalesque, such debasements are embedded in the celebration of collectivity. Yet travesties can just as easily emerge from and inspire extreme isolation and nihilism.

Freetown residents have long socialized through a continuously evolving series of trans-ethnic yet carefully ranked clubs, associations and initiatory societies the latter often rooted in masking traditions from the Yoruba diaspora such as agugu, gelede and ojeh. Amid the astronomical unemployment and miserable urban infrastructure continuously bedevilling Freetown since the end of British colonial investment, young men have become alienated from the ostentatious wealth displayed by elite private masking traditions. Throughout the 1970s and 1980s, disenfranchised youths built their own societies known as ordehleh using resourceful creativity and masses of followers (Nunley 1987), and, in the postwar era, many of these societies have now become establishment institutions in their own right. Yet kaka debuls have abandoned mimetic tactics, and instead parade exclusion and destitution. Kaka debuls infect 'high' societies of elite maskers with the 'lowest' dregs of city experience: garbage, sewage, marginal and volatile youth (Stallybrass and White 1986: 125-48). Their purpose is not inversion of value, but an impish - at once comic and sinister - confusion of value, a challenge to the elite's right to dictate the terms of propriety. 
Gongoli's own history may be a variation on that of the kaka debuls, rooted in marginal and migrant urban populations, ${ }^{9}$ and they share a contemporary milieu, often rubbing shoulders in the margins of festivities in Freetown and bigger towns. Moreover, they share an aesthetic orientation towards disorder. Rather than parodying any particular form, they travesty the very ideals of masking itself, toying with surface appearances in ways that suggest a refusal to play by society's strict regulation of individual identity.

\section{Grey-face comedians}

The contemporary figures that best satirize the generation gap are young comedians on video clips, radio programmes and street corners, sporting, for lack of a better term, 'grey-face' (Figure 6). These young men paint on ludicrous white beards, moustaches and eyebrows and dress in absurd outfits; some of these incorporate insignias of the elite, such as elders' caps or police uniforms, while some are purely surreal, such as discarded wetsuits or oversized novelty glasses. Thus clad, they strike contorted postures that amusingly juxtapose the stiffness of age with limber licentiousness, chin and buttocks extended in opposition, arms akimbo, legs bowed, feet pigeon-toed. They strut pompously or gyrate awkwardly and indecently to accelerated disco tracks. They speak in equally contorted Krio, mangling phrases and tumbling into Mende or coarse caricatures of other languages. From the safely ambiguous position of the absurd elder, these comedians mock a number of other figures - breaking into stereotypical 'Chinese' gibberish and kung fu battles, for example. Yet the character of the inept elder is the fulcrum around which all their farces pivot.

The comedic characters are old men beyond their time, struggling to keep up with the rapid changes of contemporary life, from electronic music to slang. Country bumpkins lost amidst contemporary cosmopolitanism, they try to hide their rural roots but fail embarrassingly, succumbing to criminal scams or falling foul of the law for breaking the simplest of rules. These youths and their audiences recognize that modernity requires trickster-like guile, as many other scholars argue (Pype 2010; Shipley 2013; White 1999), and their soft critique of age and infirmity puts old men in their place. Yet comedians with whom I spoke emphasized a different role for their work than social critique: development, the buzzword of the post-war moment. They argue that comedy offers a release from stresses, tensions and hostilities that build up in everyday life. Many of the artists confessed to feelings of antisocial and unproductive aggression themselves before they found the outlet of humour.

The immediate touchstone for these performers is the Professionals, a team of Freetown comedians who lampooned countryfolk, ethnic feuds and political corruption through hugely popular radio and stage plays in the 1980s and early 1990s, popularizing the style of painted beards and inept elders through characters

\footnotetext{
${ }^{9}$ Sierra Leone museum records apparently date Gongoli's first Freetown appearance to entertainments by Ghanaian soldiers garrisoned in 1914 (Richards 1977: 69). Although it is unlikely that they originated Gongoli, Ghanaians are widely recognized as the founders of jollay debuls, popular acrobatic maskers who often parade alongside other urban devils such as ordehleh and whose forms are frequently travestied as kaka debuls.
} 


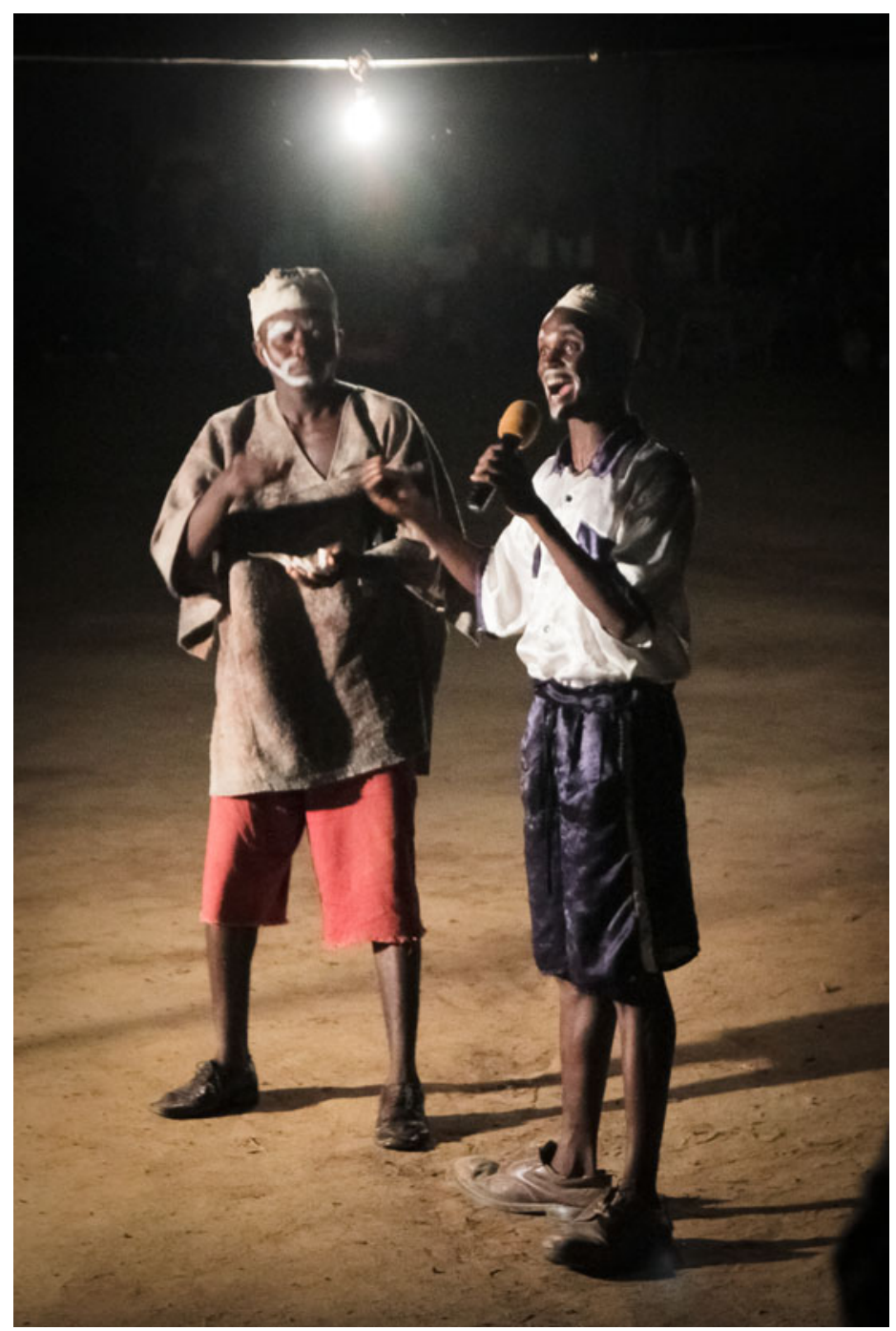

FIGURE 6 The Sharp Six Comedians in 'grey-face' during a guest appearance at a Warrior Cultural and Mystical Power Dance Troupe show, Bo, Kakua Chiefdom, 2012.

such as 'Lord Bongo' and 'Dandongo' (see Michels 2010). The style owes much to other regional comedy, such as Ghana's concert party and Nigeria's Yoruba travelling theatre, and all these forms drew from popular music and oral literatures such as Ananse stories, as well as from Hollywood films including those featuring Al Jolson in blackface makeup (Barber 2003; Cole 2001). Comedians share styles, skits and performance milieus with Gongoli, and occasionally claimed to me that only their poverty keep them from obtaining their own gongoli masks. Meanwhile, 
many gongoli performers insist that these new-fangled comedians have stolen all their best gags without so much as a 'thank you'.

\section{Musa Wo}

The debasement of elders through comedy acts and gongoli performance has unsettling connotations in Sierra Leone's recent history, when the generation gap has often become a social and economic chasm. African governance since the 1980s has been dubbed a 'state of travesty' (Obadare 2010: 102) due to neoliberal political and economic collapse that produces disjunction between effort and effect: labour does not guarantee income, payments do not guarantee services, votes do not guarantee governance. Laughter is the means by which those caught up in the churn of state failures distance themselves from dehumanizing effects by restoring a 'mask' of self-possession behind which one can ridicule misery and the grotesque excesses of performative power that is nonetheless impotent (Mbembe 2007; Mbembe and Roitman 1995: 352).

The dark and futile side of power is lampooned in Mende oral history by a disturbing series of brutal epics devoted to the twisted figure of Musa Wo. Rarely performed, Musa Wo narratives are a travesty of the Sundiata Keita epic; both figures rise from superhuman births to retaliate against injustice, but whereas Sundiata unites the Mali empire, Musa Wo embarks on adventures of comic and cosmic destruction. Musa Wo stories are exhausting because they never end, the implication being that the chaos unleashed is interminable (Cosentino 1979: 404). Without social boundaries, Musa Wo's self-centred power dissolves into pointless mayhem.

Musa Wo suggests the dangers of latent egomania possessed by any agentive individual. Frustrations with the distance between one's interior life and one's exterior reality, between one's dreams and one's struggles, between one's efforts and one's rewards, often threaten to boil over into desperate action. At such times, inversions originally designed to dissolve into joking laughter may become models of rebellion that metastasize into virulent terror. If a joke suggests that anything is possible, the possible 'anything' is more of a threat than a promise (Douglas 1968; Pelton 1980: 248-51). A thin line separates play from conflict, and minimal effort moves one frame to the other (Bateson 1972: 39). In Mende, $k$ o refers to both 'war' and 'game', suggesting, as Huizinga does, that the connection is more than metaphor (1949: 89). During the Sierra Leone Civil War, the model of Musa Wo, along with ritual inversions such as initiations, framed war as a liminal time in which hierarchies and moral values were suspended in the name of radical social transformation (Carey 2006; Ellis 2006). Brutal violence, from dismemberment to cannibalism, was used to demonstrate and reinforce the utter chaos inspired by elders' failure to govern.

The spider trickster Ka Silo's gluttony and Musa Wo's delinquency exceed the frontiers of Mende conduct while exemplifying contrasting dimensions of selfserving, antisocial behaviour; Ka Silo personifies the disastrous threats to oneself, Musa Wo the catastrophic threats to society at large (Cosentino 1979: 415-16). Between these two extremes lie the widely varying political intentions of other conventions - gonde, kaka debuls, grey-face comedians. Some discredit difference and uphold the status quo, while others undermine authority and insinuate change. Yet all play within the distance between individual interior 
and collective exterior. Siloh Gongoli's seemingly innocuous celebrity exemplifies this aesthetic with an inimitable embodiment of exceptional individuality.

\section{Conclusion: outsider as individual}

The comedy of Gongoli and the Mende aesthetic of shamelessness are rooted in the recognition that the masks we wear in communal life are not deceptions but a necessary condition of social interaction. As in Ghana's television melodramas (themselves modern Ananse trickster stories), comedy cascades from failures to protect one's private life, and, as Shipley notes, 'the ultimate moral lesson ... is about masking an interior self or denying its existence through effective public control and measured, stylish performance' (2013: 71). The gongoli performer's inability to keep his head together, both figuratively and literally, incarnates our own bumbling attempts to maintain our social masks and echoes social anxieties about the exposure and vulnerability of personal and group agency, especially given Mende society's valuation of discretion and secret power. Such shameless exposures titillate, but they also threaten to incur personal stigma and overthrow social order. The slip of Gongoli's mask recreates, then mitigates, such paranoia.

Yet, while Gongoli exemplifies dissonance between self and mask, Siloh Gongoli undermines it. Contemplating Siloh and his alter ego provokes reflections that are not contradictory, but rather complementary, as one loses track of where one figure ends and the other begins. The parade of mirroring characteristics between Siloh and Gongoli is comical not because of their discrepancies but because of their congruities. When the mask slips, we expect to be confronted with disruptive difference. Instead, we witness reassuring similarity. We can only hope that our own masks are so superfluous, that our own interior and exterior lives are so in harmony.

Spectators find Siloh Gongoli humorous for any number of personal reasons. Some must relish their own self-aggrandizing superiority provoked by his foibles. Some clearly enjoy kindly, if patronizing, affection for Siloh Gongoli's childlike naivety. There are those who applaud his satirical critique of local characters and institutions. Certainly, many must appreciate what Cosentino recognizes as the core pleasures of 'Mende ribaldry' and the humour of the grotesque: a release of 'the tension between reality and appearance' (1982: 67). Siloh Gongoli's bungled efforts at anonymity epitomize liberation from the exhausting maintenance of the mask of public propriety.

However, the point here is not to define why spectators find Siloh Gongoli hilarious, but rather to clarify why finding him funny is permitted at all. Like much broad comedy, this humour is predicated on a transgression ('He slipped and fell!') followed by the relief of realizing the transgression is harmless ('But he's not really hurt'). Unlike slapstick rooted in bodily mishaps, Siloh Gongoli's transgressions are not physical or personal, but social. If he stood for any particular community, his actions would be appalling. If he had a family, his impropriety would reflect their moral failures. If he had a distinguished patron, his recklessness would undermine his leader's prestige. If he had an initiatory society, his indiscretions would suggest the weakness of their unity. Having none of these, Siloh Gongoli, the consummate loner, shames no one but himself. 


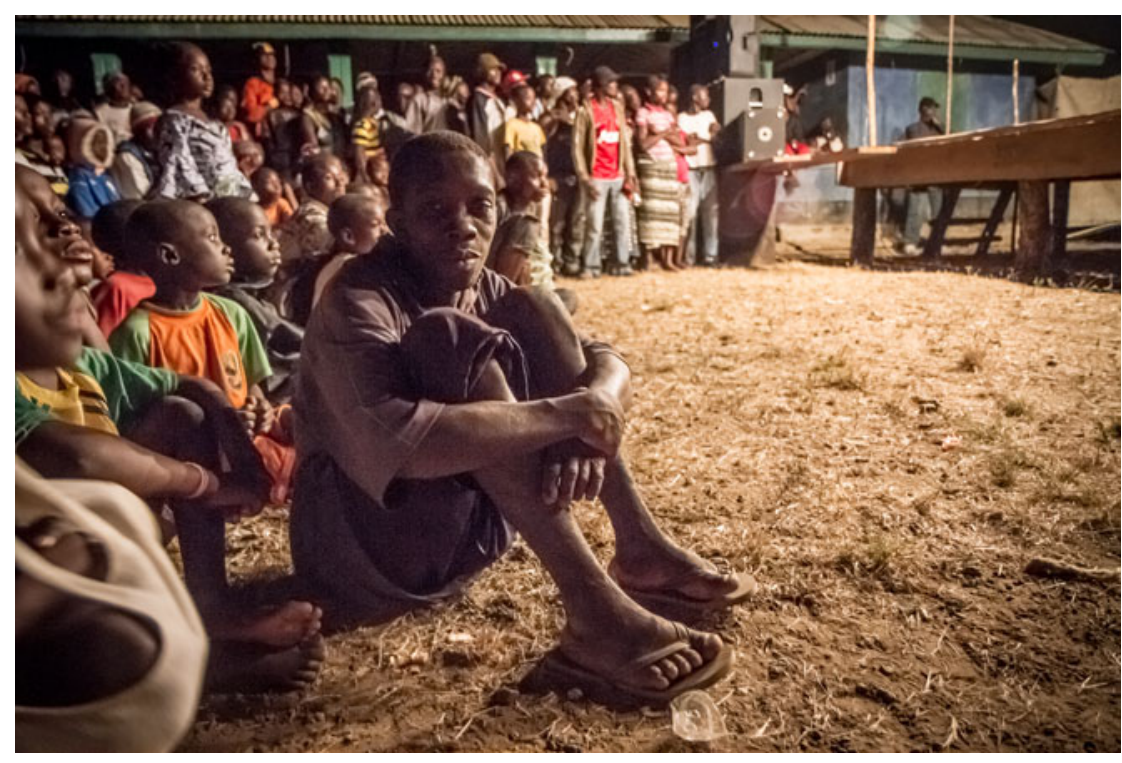

FIGURE 7 Siloh, Gboaama, Njaluahun Chiefdom, 2013.

Having first met Siloh with the Mammy Yoko troupe, I had presumed that a fellow performer had 'cast' Siloh as the company's Gongoli. I was surprised to later hear that Siloh had fallen in with the troupe with his gongoli mask already in tow. Throughout my subsequent travels around Eastern Sierra Leone, I often ran into Siloh without Mammy Yoko, roving from highway community to highway community and presumably living off simple manual labour and the generosity of his neighbours. When I found him in January 2013, he had temporarily joined up with popular recording artist Steady Bongo, cavorting onstage among the band's shiny drum kit and electric guitars. In 2015, I heard he had become a radio star, spouting nonsense answers to questions about education and Ebola prevention and inadvertently offering sensitization messages through foolish inversion. Wherever I encountered him, Siloh maintained the same character and celebrity, a consistency that provided him with the same deceptively ageless aura as Gongoli (Figure 7).

Siloh Gongoli's appeal is no doubt rooted in the consonance between the personality of the performer and the character of the devil he portrays. This otherwise delightful congruity extends into Siloh's personal life. He is the archetypical vagabond artist, free from both the support and constraints of a community of his own. This bittersweet alienation, perhaps the inevitable outcome of social exception, never seemed to bother Siloh too much. He was always surrounded by a provisional assemblage of companions, whether children, unemployed young men, or fellow performers. In this sense, his lifestyle mirrored not only that of Gongoli, but that of most disenfranchised and displaced young men whose lives have been upset by past wartime violence and present-day poverty. For disheartened and forsaken youths, the only available expressions of individuality seem to be rejections of social norms that only push them into further isolation. Despite 
his clear lack of material prosperity, Siloh's celebrity spoke in some sense to an aspiration unachievable for many: that regardless of their foibles, they might still find a place in their communities.

Despite these sombre circumstances, there is something unquestionably 'sweet' - both 'enjoyable' in the sense of the Mende term neEnga ('sweet', 'delicious', or generally 'pleasant') and 'adorable' in the sense given by colloquial English about those disarming moments when Siloh Gongoli, sitting on the sidelines while other devils perform, is playfully teased by the women around him for lifting up his mask so as to watch his colleagues. In the anxious fumbling with which Siloh reburies his abashed and all-too-exposed visage, we lose track of the distinction between where Gongoli stops and Siloh begins. This blurring of identities only reiterates Gongoli's fundamental essence as individuality overflowing.

\section{Acknowledgements}

This article would not have been possible without the generous hospitality of the Mammy Yoko Cultural Dance Troupe and Moonlight Disco and its leaders, Baggie Korvoma, Moriba Koroma and Lansana Lebbie, as well as that of the many villages we visited together. Research and writing received logistical support from Fourah Bay College and financial support from the Social Science Research Council, the Charlotte W. Newcombe Foundation, the University of California Los Angeles, and the Mahindra Humanities Center at Harvard. Thanks to the reviewers at Africa for many clarifying comments. Many thanks to Susan Elizabeth Gagliardi for framing the questions this article seeks to explore, and to Donald Cosentino, whose work as adviser and scholar offered many models of how to answer them.

\section{References}

Bakhtin, M. (1981) The Dialogic Imagination: four essays. Austin TX: University of Texas Press.

Barber, K. (1981) 'How man makes god in West Africa: Yoruba attitudes towards the Orisa', Africa 51 (3): 724-45.

Barber, K. (2003) The Generation of Plays: Yoruba popular life in theater. Bloomington IN: Indiana University Press.

Bateson, G. (1972) Steps to an Ecology of Mind. New York NY: Ballantine Books.

Bellman, B. (1984) The Language of Secrecy: symbols and metaphors in Poro ritual. New Brunswick NJ: Rutgers University Press.

Bergson, H. (1914) Laughter: an essay on the meaning of the comic. New York NY: Macmillan.

Bolten, C. (2012) "We have been sensitized": ex-combatants, marginalization, and youth in postwar Sierra Leone', American Anthropologist 114 (3): 496-508.

Boone, S. A. (1986) Radiance from the Waters: ideals of feminine beauty in Mende art. New Haven CT: Yale University Press.

Cannizzo, J. (1983) 'The shit devil: pretense and politics among West African urban children' in F. E. Manning (ed.), The Celebration of Society: perspectives on contemporary cultural performance. Bowling Green $\mathrm{OH}$ : Bowling Green University Popular Press. 
Carey, M. (2006) "“Survival is political”: history, violence, and the contemporary power struggle in Sierra Leone' in E. G. Bay and D. L. Donham (eds), States of Violence: politics, youth, and memory in contemporary Africa. Charlottesville VA: University of Virginia Press.

Castle, T. (1986) Masquerade and Civilization: the carnivalesque in eighteenthcentury English culture and fiction. Stanford CA: Stanford University Press.

Cole, C. M. (2001) Ghana's Concert Party Theatre. Bloomington IN: Indiana University Press.

Cole, H. M. (1985) 'Introduction: the mask, masking, and masquerade arts in Africa' in I Am Not Myself: the art of African masquerade. Los Angeles CA: Museum of Cultural History, University of California.

Cosentino, D. J. (1979) 'Patterns in domeisia: the dialectics of Mende narrative performance'. PhD thesis, University of Wisconsin.

Cosentino, D. J. (1982) 'Mende ribaldry', African Arts 15 (2): 64-88.

d'Azevedo, W. L. (1962) 'Some historical problems in the delineation of a Central West Atlantic region', Annals of the New York Academy of Sciences 96 (2): 512-38.

d'Azevedo, W. L (1973) 'Sources of Gola artistry' in W. L. d'Azevedo (ed.), The Traditional Artist in African Societies. Bloomington IN: Indiana University Press.

Dentith, S. (2000) Parody. London: Routledge.

Douglas, M. (1968) 'The social control of cognition: some factors in joke perception', Man 3 (3): 361-76.

Durkheim, É. (1915) The Elementary Forms of the Religious Life: a study in religious sociology. London: G. Allen \& Unwin.

Ellis, S. (2006) The Mask of Anarchy: the destruction of Liberia and the religious dimension of an African civil war. New York NY: New York University Press.

Ferme, M. (2001) The Underneath of Things: violence, history, and the everyday in Sierra Leone. Berkeley CA: University of California Press.

Goffman, E. (1963) Stigma: notes on the management of spoiled identity. New York NY: Simon and Schuster.

Hommel, W. L. (1981) 'Form and meaning of masks in three Mende societies'. $\mathrm{PhD}$ thesis, Indiana University.

Honwana, A. (2012) The Time of Youth: work, social change, and politics in Africa. Sterling VA: Kumarian Press.

Huizinga, J. (1949) Homo Ludens. London: Taylor \& Francis.

Hutcheon, L. (2000) A Theory of Parody: the teachings of twentieth-century art forms. Champaign IL: University of Illinois Press.

Jackson, M. (2005) Existential Anthropology: events, exigencies and effects. New York NY: Berghahn Books.

Jędrej, M. C. (1976) 'Medicine, fetish and secret society in a West African culture', Africa 46 (3): 247-57.

Jędrej, M. C. (1991) 'West African masks and social control', Journal of Museum Ethnography 3: 1-14.

Klapp, O. E. (1949) 'The fool as a social type', American Journal of Sociology 55 (2): 157-62.

Little, K. L. (1965) 'The political function of the Poro: part I', Africa 35 (4): 349-65.

Livingston, J. (2005) Debility and the Moral Imagination in Botswana. Bloomington IN: Indiana University Press. 
MacCormack, C. P. (1979) 'Sande: the public face of a secret society' in B. JulesRosette (ed.), The New Religions of Africa. Norwood NJ: Ablex.

Mbembe, A. (2007) On the Postcolony. Berkeley CA: University of California Press.

Mbembe, A. and J. Roitman (1995) 'Figures of the subject in times of crisis', Public Culture 7 (2): 323-52.

Michels, P. (2010) 'One of Sierra Leone's most beloved comedians took refuge in Dallas from his country's civil war. What could have turned him into a killer?', Dallas Observer, 25 November.

Migeod, F. W. H. (1916) 'The Poro society: the building of the Poro house and making of the image', Man 16: 102-8.

Murphy, W. P. (1998) 'The sublime dance of Mende politics: an African aesthetic of charismatic power', American Ethnologist 25 (4): 563-82.

Newell, S. (2012) The Modernity Bluff: crime, consumption, and citizenship in Côte d'Ivoire. Chicago IL: University of Chicago Press.

Nunley, J. (1987) Moving with the Face of the Devil: art and politics in urban West Africa. Champaign IL: University of Illinois Press.

Obadare, E. (2010) 'State of travesty: jokes and the logic of socio-cultural improvisation in Africa', Critical African Studies 2 (4): 92-112.

Pelton, R. D. (1980) The Trickster in West Africa: a study of mythic irony and sacred delight. Berkeley CA: University of California Press.

Peters, K. (2011) War and the Crisis of Youth in Sierra Leone. Cambridge: Cambridge University Press.

Peters, K. and P. Richards (1998) "Why we fight": voices of youth combatants in Sierra Leone', Africa 68 (2): 183-210.

Phillips, R. B. (1995) Representing Woman: Sande masquerades of the Mende of Sierra Leone. Los Angeles CA: UCLA Fowler Museum of Cultural History.

Pype, K. (2010) 'Of fools and false pastors: tricksters in Kinshasa's television fiction', Visual Anthropology 23 (2): 115-35.

Reid-Cunningham, A. R. (2009) 'Anthropological theories of disability', Journal of Human Behavior in the Social Environment 19 (1): 99-111.

Reinhardt, L. R. (1976) 'Mende carvers'. PhD thesis, Southern Illinois University.

Reinhardt, L. R. (1979) 'Mende secret societies and their costumed spirits' in J. M. Cordwell and R. A. Schwarz (eds), The Fabrics of Culture: the anthropology of clothing and adornment. The Hague: Mouton.

Richards, J. V. O. (1977) 'Santigie Sesay: Sierra Leone carver', African Arts 11 (1): 65-92.

Rose, M. A. (1993) Parody: ancient, modern and post-modern. Cambridge: Cambridge University Press.

Shepler, S. (2014) Childhood Deployed: remaking child soldiers in Sierra Leone. New York NY: NYU Press.

Shipley, J. W. (2013) 'Television tricksters: parody and contradiction in Ghanaian melodrama', Social Text 31 (4 (117)): 49-76.

Siegmann, W. C. and J. Perani (1976) 'Men's masquerades of Sierra Leone and Liberia', African Arts 9 (3): 42-7.

Sommers, M. (2012) Stuck: Rwandan youth and the struggle for adulthood. Athens GA: University of Georgia Press.

Stallybrass, P. and A. White (1986) The Politics and Poetics of Transgression. Ithaca NY: Cornell University Press. 
White, B. W. (1999) 'Modernity's trickster: "dipping" and "throwing" in Congolese popular dance music', Research in African Literatures 30 (4): 156-75. Willeford, W. (1969) The Fool and his Scepter: a study in clowns and jesters and their audience. Evanston IL: Northwestern University Press.

\begin{abstract}
Grotesque and vulgar, the masked character Gongoli upends the codes of Mende decorum in his madcap pursuit of laughs. His impropriety goes so far as to allow his mask to fall, comically revealing the identity of his dancer and subverting the anonymity so elemental to his fellow spirits' vaunted status. Yet despite such transgressions, he stands among the most beloved figures of Sierra Leone's rich performance traditions. Gongoli's popularity hinges on his irreverence towards the fundamental laws of masked dance, laws that also regulate the balance between individual agency and communal responsibility, between internal desire and external restraint. The only quality necessary to play Gongoli is shamelessness (ngufe baa), and the greatest performers are acrobats braving risks that are not physical, but social. This article follows Siloh, an itinerant performer whose celebrity inheres in his uncanny similarity to the Gongoli he often plays. The composite figure Siloh Gongoli exemplifies a comic aesthetic relished throughout Sierra Leone in storytelling, ritual, festivals, videos and radio shows. Although mobilized for different ends, each of these conventions undermines principles of self-effacement, gerontocratic privilege and esoteric power by shamelessly playing with and within the existential tensions between interior and exterior selves.
\end{abstract}

\title{
Résumé
}

Grotesque et vulgaire, le personnage masqué Gongoli bouleverse les codes de la bienséance mendé dans sa folle quête de faire rire. Son inconvenance va jusqu'à s'autoriser à baisser le masque, révélant de façon comique l'identité de son danseur et subvertissant l'anonymat si fondamental au statut de ses fameux esprits compagnons. Pourtant, malgré ces transgressions, il figure parmi les personnages les plus chéris des riches traditions du spectacle au Sierra Leone. La popularité de Gongoli repose sur son irrévérence vis-à-vis des lois fondamentales de la danse masquée, des lois qui régulent également l'équilibre entre action individuelle et responsabilité collective, entre désir interne et contrainte externe. La seule qualité nécessaire pour incarner Gongoli est l'impudence (ngufe baa), et les meilleurs artistes sont des acrobates qui bravent des risques non pas physiques mais sociaux. Cet article s'intéresse à Siloh, un artiste itinérant dont la célébrité tient à sa ressemblance troublante au Gongoli qu'il incarne souvent. Le personnage composite Siloh Gongoli exemplifie une esthétique comique appréciée partout au Sierra Leone, que ce soit dans les contes, les rituels, les festivals ou les programmes radiophoniques et télévisuels. Bien que ces conventions aient des finalités de mobilisation différentes, chacune d'elles ébranle les principes de l'effacement de soi et du privilège géroncratique, et masque le pouvoir en se jouant sans vergogne des tensions existentielles entre le soi intérieur et le soi extérieur. 